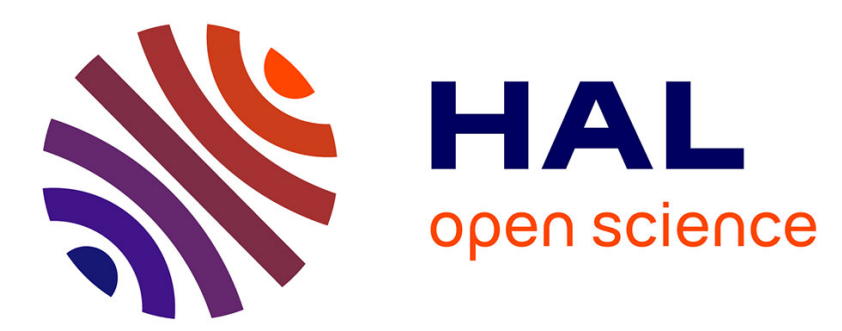

\title{
A power shaft for the Munich MP-tandem
}

\author{
H. Steffens, L. Rohrer, S.J. Skorka
}

\section{To cite this version:}

H. Steffens, L. Rohrer, S.J. Skorka. A power shaft for the Munich MP-tandem. Revue de Physique Appliquée, 1977, 12 (10), pp.1583-1584. 10.1051/rphysap:0197700120100158300 . jpa-00244373

\section{HAL Id: jpa-00244373 https://hal.science/jpa-00244373}

Submitted on 1 Jan 1977

HAL is a multi-disciplinary open access archive for the deposit and dissemination of scientific research documents, whether they are published or not. The documents may come from teaching and research institutions in France or abroad, or from public or private research centers.
L'archive ouverte pluridisciplinaire HAL, est destinée au dépôt et à la diffusion de documents scientifiques de niveau recherche, publiés ou non, émanant des établissements d'enseignement et de recherche français ou étrangers, des laboratoires publics ou privés. 


\title{
A POWER SHAFT FOR THE MUNICH MP-TANDEM
}

\author{
H. STEFFENS, L. ROHRER and S. J. SKORKA
}

Beschleunigerlaboratorium der Universität und Technischen

Universität München, 8046 Garching, Hochschulgelände, R.F.A.

\begin{abstract}
Résumé. - On décrit un arbre tournant isolé pour la transmission de puissance, développé pour le Tandem MP de Munich. Cet arbre transfert une puissance de plusieurs $\mathrm{kW}$ à des pompes à vide et à un équipement d'optique de faisceau dans des régions situées à un potentiel électrostatique élevé et a déjà fonctionné sans problème pendant plus de 3500 heures. La conception relativement simple peut être adaptée à des systèmes similaires dans les accélérateurs électrostatiques horizontaux ou verticaux. Il peut être adapté facilement pour des transmissions de puissances plus élevées.
\end{abstract}

Abstract. - A rotating, insulated power shaft developed for the Munich MP-Tandem is described. The shaft transfers energy at a rate of several $\mathrm{kW}$ to vacuum pumps and beam optical equipment in regions of high electrostatic potential and has now been running trouble free for over $3500 \mathrm{~h}$. The relatively simple design can be adapted for similar devices in horizontal or vertical electrostatic accelerators with a suitable column grading pitch. It can easily be upgraded for higher energy transfer rates.

The conversion program of the Munich MP tandem includes the operation of ion getter pumps in all dead sections and of a lens in the central dead section of the low energy column. The energy requirement of the terminal components is supplied by two $1.5 \mathrm{~kW}$ generators driven by the Pelletron charging chains. For the energy transfer to the dead sections a rotating power shaft was developed. The power generators which simultaneously serve as bearings to support the shaft in the dead sections were part of the development, too.

The figures 1 and 2 show the general layout. Near the tank bases on both ends of the column an asynchronous motor is mounted which is directly coupled to the shaft. The shaft runs outside the column structure but shielded within the equipotential rings and is supported at four positions between dead sections. The distance between individual supports is $40 \mathrm{~cm}$ only.

With regards to a simple design of the generators and their limited size a rotational frequency of

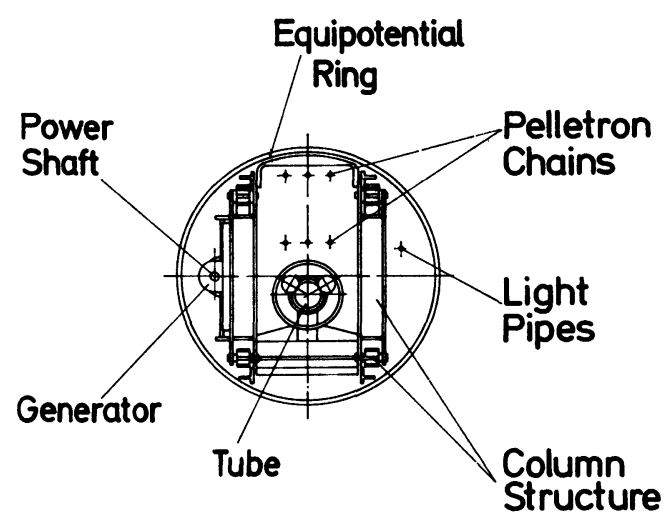

Fig. 1. - HE-column of the MP-Tandem with power shaft and supports. Equipotential rings and several other details not shown.

$3000 \mathrm{rpm}$ was chosen. The generators are excited by permanent magnets and show a soft voltage-current characteristic matched to the requirements of the triode ion getter pumps. The shafts end at the last dead sections near the terminal but can easily extended to the terminal in case of need.

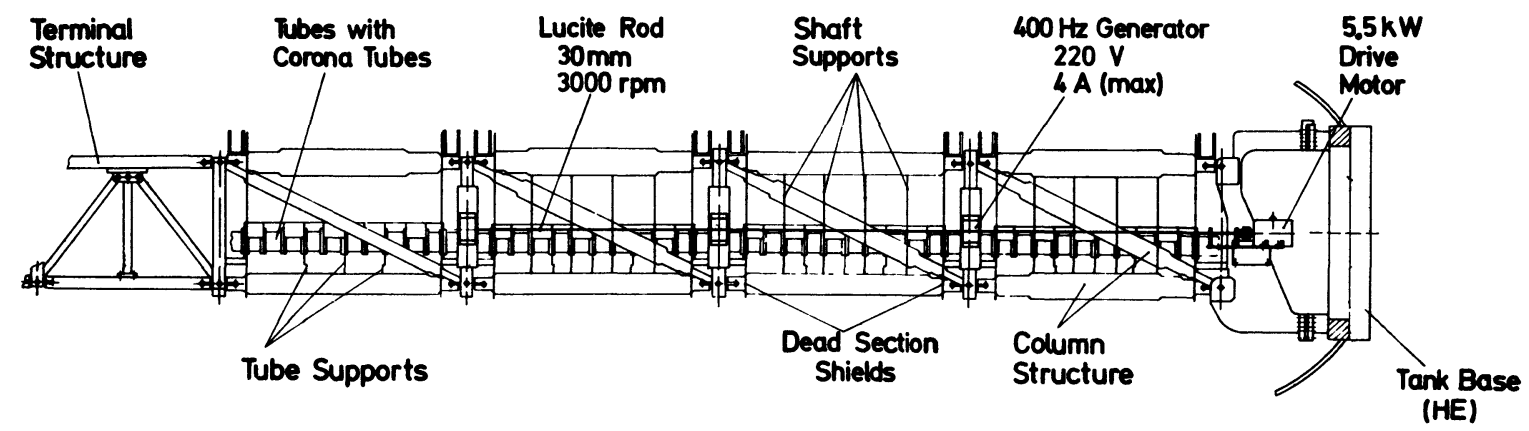

FIG. 2. - Cross section of the MP-Tandem showing the position of the power shaft and other important components. 
Selecting the material for the shaft the electrical properties of lucite and delrin were compared in high voltage tests using the terminal to tank field of the tandem. Except cleaning the surfaces no special treatment (eg. drying) of the test rods was applied. While along the delrin rod breakdown occured at gradients less than $1.4 \mathrm{MV} / \mathrm{m}$, the lucite rods could withstand more than $3 \mathrm{MV} / \mathrm{m}$ (1). The rated column gradient in the upgraded MP is near $2 \mathrm{MV} / \mathrm{m}$. Lucite was chosen based on these results although the mechanical properties of lucite are less favorable than those of delrin or nylon.

Mechanical tests delivered for lucite rods of $30 \mathrm{~mm}$ dia. an average breaking torque of $350 \mathrm{Nm}$. Since lucite rods are commercially not available in the necessary length proper pieces had to be glued together. The adhesive strength corresponded to a breaking torque of about $300 \mathrm{Nm}$. The coupling to the generators was achieved by conical metal tubes (Fig. 3) glued to the lucite using a quasi-elastic adhesive. The average breaking torque of these connectors turned out to be about $200 \mathrm{Nm}$. The maximal torque of the $5.5 \mathrm{~kW}$ standard motor is around $50 \mathrm{Nm}$.

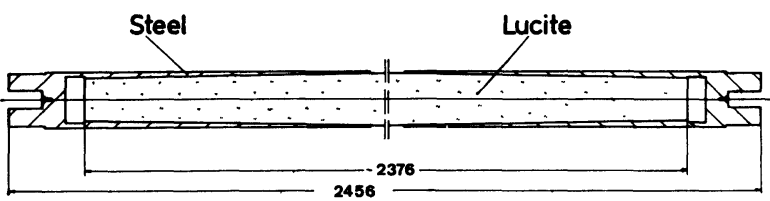

FIG. 3. - Lucite shaft with conical lucite to metal coupling at the ends.

The additional supports of the shaft between the dead sections are equipped with carefully selected rubber inserts for optimal damping and covered with electrostatic shields as shown in figure 4 and 5 . They are mounted to the MP column structure in a way that no shorting of individual column sections was necessary. The configuration was laboratory tested up to more than $4000 \mathrm{rpm}$ with no signs of mechanical resonances. All bearings were filled with a special grease (2) suitable for use in $\mathrm{SF}_{6}$. Since this grease is more viscous than standard lubricants, the bearings had to be conditioned before installation with extra cooling for about $90 \mathrm{~h}$.

(1) For more details on these tests see annual report 1974, p. 10, Beschleunigerlaboratorium der Universität und Technischer Universität München.

(2) Barierta-I-SL, Klüber Lubrication München, KG.

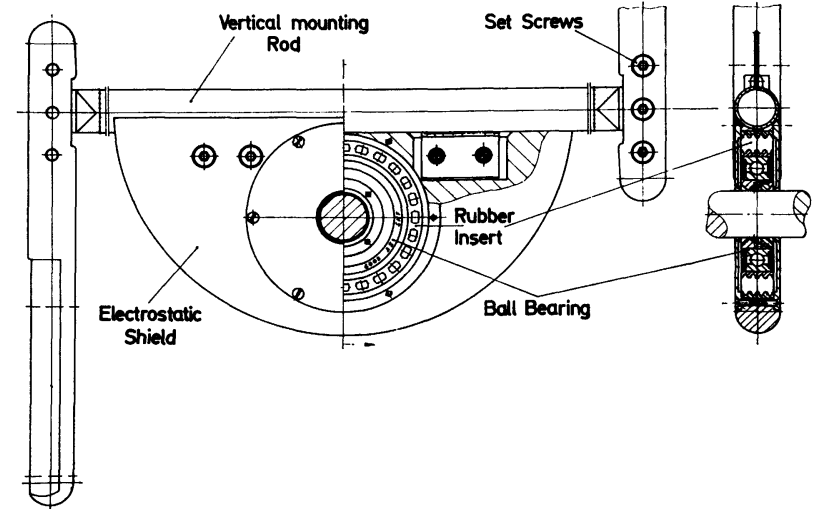

FIG. 4. - Supports with ball bearing rubber insert, electrostatic shields and structure for mounting to the column.

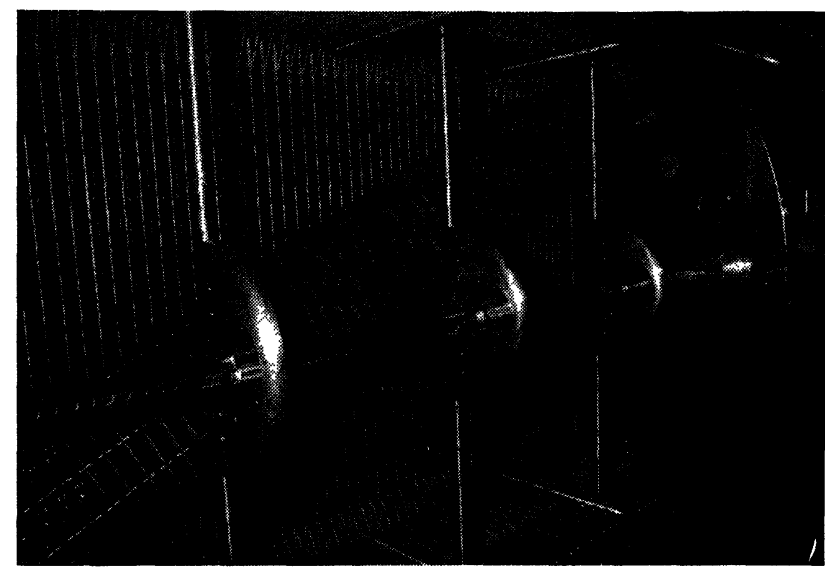

Fig. 5. - Power shaft of the MP-Tandem Munich, showing the additional supports between dead sections.

During operation the shaft exhibits transversal oscillations with amplitudes of less than $0.5 \mathrm{~mm}$. Axial oscillations do not occur. During start up an angular distortion between the first and the last generator of $12^{\circ}$ was observed by comparing the a.c. phases of the generator voltage. This distortion decays aperiodically.

The system was already installed during the high voltage tests of the MP tandem without tubes and showed no signs of damage or breakdown tracks even at terminal voltage of over $16 \mathrm{MV}$. No interference of the system with the high voltage performance of the accelerator could be observed.

Acknowledgements. - The authors would like to thank Dr. A. Langsdorf, ANL, for detailed and valuable advices. 